American Journal of Agricultural and Biological Sciences 6 (2): 273-278, 2011

ISSN 1557-4989

(C) 2011 Science Publications

\title{
Soybean Response to 1-Aminocyclopropane-1-Carboxylate Deaminase-Producing Pseudomonas under Field Soil Conditions
}

\author{
${ }^{1}$ Edi Husen, ${ }^{1}$ Aris Tri Wahyudi, ${ }^{1}$ Antonius Suwanto and ${ }^{2}$ Giyanto \\ ${ }^{1}$ Department of Biology, Faculty of Mathematics and Natural Sciences, \\ ${ }^{2}$ Department of Plant Protections, Faculty of Agriculture, \\ Bogor Agricultural University (IPB), Bogor, Indonesia, Jl. Agatis-Kampus Dramaga, \\ Bogor 16680, Indonesia
}

\begin{abstract}
Problem statement: 1-Aminocyclopropane-1-Carboxylate (ACC) deaminase-producing bacteria have been known to promote plant growth by decreasing ethylene inhibition of various plant processes. However, their efficacy under field soil conditions may vary depending on the range and variability of the environmental factors. This study examined the ability of eight promising isolates of ACC deaminase-producing Pseudomonas to enhance soybean growth under acidic and low fertility status of field soil conditions. Approach: The bacteria were formulated into peat-based carrier and used to inoculate soybean seeds. Cell viability in the carrier was evaluated periodically. The number of bacterial population at the time of seed inoculation was above $10^{7} \mathrm{cell}^{-1}$. Treated and untreated seeds were grown in plots $\left(5 \times 4 \mathrm{~m}^{2}\right)$ and set in a randomized complete block design with 3 replicates. Observations were made at $30 \mathrm{~d}$ after planting for shoot height and weight, number of nodules and at harvesting for number of pods and yield. Results: Three out of eight isolates significantly increased soybean growth exhibited by higher number of nodules and pod filling and higher seed dry weight than those of untreated control. Those five remaining bacteria, on the contrary, inhibited soybean growth indicating that other unknown external factors influenced or covered the beneficial trait of ACC deaminase. Conclusion: Bacteria having ACC deaminase activities could be truly plant growth promoting bacteria providing that their beneficial effects are consistent at a wide range of environmental conditions.
\end{abstract}

Key words: ACC deaminase, environmental factors, growth promotion, Pseudomonas, soybean

\section{INTRODUCTION}

A number of 1-Aminocyclopropane-1-Carboxylate (ACC) deaminase-producing bacteria have been known to promote plant growth by ameliorating plant growth inhibition caused by ethylene production (Glick et al., 1995; Penrose et al., 2001; Mayak et al., 2004; Ma et al. 2003). These bacteria hydrolyze root ACC (ethylene precursor) into ammonia and $\alpha$-ketobutyrate as their sources of carbon and nitrogen (Honma and Shimomura 1978; Jacobson et al., 1994; Glick et al., 1998); thereby reducing ethylene synthesis. Various findings in the last few years also demonstrate their ability to ameliorate plant stress caused by various biotic and abiotic conditions, such as caused by high concentration of indole-3-acetic acid (Mayak et al., 1997), water logging (Grichko and Glick 2001), nutritional shortage (Belimov et al., 2002), drought (Mayak et al., 2004), high salts (Saravanakumar and Samiyappan, 2007) and the presence of pollutants (Reed and Glick, 2005; Belimov et al., 2001) and plant pathogens (Wang et al,. 2000; Dey et al., 2004; Shaharoona et al., 2006). Our previous experiments using local isolates of ACC deaminase-producing Pseudomonas under growth chamber showed the ability of these isolates in enhancing soybean growth (Husen et al., 2009). However, the extent by which plant responds to these bacteria under field soil conditions may vary since the environmental factors are variable during plant growth.

Reports by Shaharoona et al. (2006; 2007) confirmed that the effectiveness of ACC deaminaseproducing bacteria on plant growth was influenced by nutrient status of the media which could be related to ethylene production (Abeles et al., 1992). On the other hand, Glick et al. (2007) concluded that the efficacy of these bacteria on plant growth may not be clearly

Corresponding Author: Aris Tri Wahyudi, Division of Microbiology, Department of Biology,

Faculty of Mathematics and Natural Sciences (MIPA), Bogor Agricultural University (IPB),

Bogor 16680; Indonesia Tel/Fax: +62-251-8622833 
observed at stress-free conditions of the plants. Moreover, unusual findings by Belimov et al. (2007) found that a single strain ( $P$. brassicacearum Am3) producing ACC deaminase may have growthpromoting, neutral, or pathogenic effects on plant growth according to the environmental conditions. These facts imply the importance of field trials to acquire a conclusive evidence whether the bacteria are truly plant growth-promoting bacteria or their beneficial effects depend on a certain environmental condition.

The present study aimed to evaluate the effects of eight promising isolates of ACC deaminase-producing Pseudomonas on soybean growth and yield under field soil conditions. Peat-based inoculants of the isolates were formulated to ensure cell viability before and after seed inoculation.

\section{MATERIALS AND METHODS}

Bacterial Isolates: Eight promising isolates of ACC deaminase-producing Pseudomonas were used in the study. The isolates, designated as Crb5, Crb12, Crb17, Crb24, Crb46, Crb47, Crb49 and Crb56 were selected based on previous research results in the laboratory and growth room experiments (Husen et al., 2009). The origin of the bacteria is from the rhizosphere of soybean grown in Plumbon agricultural area in Cirebon, West Java, Indonesia. Besides producing 1Aminocyclopropane-1-Carboxylate (ACC) deaminase (E.C.4.1.99.4) and Indole-3-Acetic Acid (IAA), the isolates were also not detected to inhibit rhizobial strains based on co-culture tests using Bradyrhizobium japonicum Bj11 and Sinorhizobium fredii Rif5.

Preparation of peat-based Inoculants: Peat-based formulation of the isolates for seed treatments was performed in the Laboratory of Soil Biology and Health, Indonesian Soil Research Institute (ISRI) and the Laboratory of Microbiology, Department of Biology, Faculty of Mathematics and Natural Sciences, Bogor Agricultural University (IPB). Each isolate from stock culture of King's B (KB) medium was first grown in Dworkin-Foster (DF) minimal salts medium (Dworkin and Foster, 1958) supplemented with either ACC or ammonium sulfate to induce and maintain the activity of ACC deaminase and then subsequently transferred to the economically modified $\mathrm{KB}$ medium. The KB medium contained $20 \mathrm{~g}$ protease peptone, 10 $\mathrm{mL}$ glycerol, $1.5 \mathrm{~g} \mathrm{~K}_{2} \mathrm{HPO}_{4}, 1.5 \mathrm{~g} \mathrm{MgSO}_{4} .7 \mathrm{H}_{2} \mathrm{O}, 15 \mathrm{~g}$ agar (for solid media) and $1000 \mathrm{~mL}$ distilled water. The modified KB medium was KB medium, except the glycerol and protease peptone were replaced with 15 $\mathrm{mL}$ molasses, $20 \mathrm{~mL}$ skimmed milk and $10 \mathrm{~mL}$ freshly coconut water. The composition of DF minimal salt medium were $4 \mathrm{~g} \quad \mathrm{KH}_{2} \mathrm{PO}_{4}, 6 \mathrm{~g} \quad \mathrm{Na}_{2} \mathrm{HPO}_{4}, 0.2 \mathrm{~g}$ $\mathrm{MgSO}_{4} .7 \mathrm{H}_{2} \mathrm{O}, 1 \mathrm{mg} \mathrm{FeSO}_{4} .7 \mathrm{H}_{2} \mathrm{O}, 10 \mu \mathrm{g} \mathrm{H}_{3} \mathrm{BO}_{3}, 10 \mu \mathrm{g}$ $\mathrm{MnSO}_{4}, 70 \mu \mathrm{g} \mathrm{ZnSO} 4,50 \mu \mathrm{g} \mathrm{CuSO}_{4}, 10 \mu \mathrm{g} \mathrm{MoO}_{3}, 2 \mathrm{~g}$ glucose, $2 \mathrm{~g}$ gluconic acid, $2 \mathrm{~g}$ citric acid, $1000 \mathrm{~mL}$ distilled water + either $0.3033 \mathrm{~g} \mathrm{~L}^{-1} \mathrm{ACC}$ or $2 \mathrm{~g} \mathrm{~L}^{-1}$ ammonium sulfate and solidified with $15 \mathrm{~g}$ agar. Except the heat-labile ACC that was filtered-sterilized using $0.2 \mu \mathrm{m}$ membrane filter, all media constituents were mixed and sterilized by autoclaving at $121^{\circ} \mathrm{C}$ for $15 \mathrm{~min}$.

Inoculant production and peat-carrier material were prepared according to the procedures described by Somasegaran and Hoben (1994). A loop full of each isolate from DF minimal salt medium was transferred to $100 \mathrm{~mL} \mathrm{~KB}$ medium and incubated in a shaker at 125 $\mathrm{rpm}$ for $48 \mathrm{~h}$ at room temperature. After $48 \mathrm{~h}$ incubation, a $50 \mathrm{~mL}$ of bacterial suspension containing $1 \times 10^{8}$ cells $\mathrm{mL}^{-1}$ was transferred to $1000 \mathrm{~mL}$ modified $\mathrm{KB}$ medium and incubated at constant shaking as described above. The growth of bacteria in the medium was periodically measured spectrophotometrically at $600 \mathrm{~nm}$ for $48 \mathrm{~h}$. Prior to peat inoculation, bacterial suspension was adjusted to give an absorbance of 0.55 at $600 \mathrm{~nm}$ which was equal to $10^{9}$ cells $\mathrm{mL}^{-1}$ (Cattelan et al., 1999). Peat material as the inoculant carrier was homogenized using 200 mesh sieve and enriched with calcium carbonate ( $4 \%$ of peat material) to increase the $\mathrm{pH}$. The mixtures were packed $40 \mathrm{~g}$ each in autoclavable plastic bags and sterilized twice (2 consecutive days) at $121^{\circ} \mathrm{C}$ for $30 \mathrm{~min}$. A $10 \mathrm{~mL}$ of bacterial suspension was injected to each of $40 \mathrm{~g}$ sterile peat under aseptic conditions and the products were stored at room temperature.

Observations for cell viability, $\mathrm{pH}$ and water content of the carrier were made at week-1, week-4 and week-12 after peat inoculation. Recovery of bacteria from the carrier was conducted according to the procedure of Zuberer (1994) and the data were present on the dry weight basis.

Soil Properties, experimental design and seed treatment: The experiment was conducted in farmer upland agricultural area in Lengkong Village, Karangpawitan Sub district, Garut District, West Java Province, Indonesia. The area is located at $07^{\circ} 12^{\prime} 35.3^{\prime \prime}$ SE and 107 57'09.4" E. A composite soil sample of Ultisol surface layer (0-20 cm depth) was collected and analyzed for soil texture, $\mathrm{pH}, \mathrm{C}$-organic and selected nutrients according to the standard procedures of the Soil Chemistry Laboratory of Indonesian Soil Research Institute (ISRI) in Bogor. Based on soil sample analyses (Table 1), the soil is acidic with fine texture (clay loam), low organic content and low fertility status. 
Am. J. Agri. \& Biol. Sci., 6 (2): 273-278, 2011

Table1: Texture and some chemical characteristic of soils used for the experiment in Lengkong Village, Karangpawitan, Garut, West Java, Indonesia

\begin{tabular}{|c|c|c|c|c|c|c|c|c|}
\hline & \multirow[b]{2}{*}{ Texture } & \multirow[b]{2}{*}{$\mathrm{pH}$} & \multirow[b]{2}{*}{$\mathrm{C}$} & \multirow[b]{2}{*}{$\mathrm{N}$} & \multicolumn{4}{|c|}{ (Extracted $\mathrm{HCl} 25 \%)$} \\
\hline & & & & & $\mathrm{P}_{2} \mathrm{O}_{5}$ & $\mathrm{~K}_{2} \mathrm{O}$ & $\mathrm{CEC}$ & BS \\
\hline Unit - & - & ---- $\mathrm{g} \mathrm{kg}^{-1}$ & ---- $\mathrm{mg} \mathrm{kg}^{-1}$ & - & $\mathrm{cmol}_{(+)} \mathrm{kg}^{-1}$ & $\%$ & & \\
\hline Value & Clay loam & 4.9 & 11 & 0.9 & 260 & 70 & 22.07 & 57 \\
\hline Status & Fine & Acidic & Low & Very low & Medium & Very low & Medium & Medium \\
\hline
\end{tabular}

The experiment used plot size of $5 \times 4 \mathrm{~m}^{2}$, which were arranged in a randomized complete block design with 3 replications for each treatment. Eight isolates and one untreated control were used as treatments. Planting distance and fertilizer application followed the existing farmer practices.

Seeds of soybean (Glycine max L. Merr.) cv. Wilis as test-plant were obtained from the Indonesian Center for Biotechnology and Genetics Resources Research and Development, Bogor. Seed treatment was conducted by mixing moist seeds (previously soaked with tap water for several min) with freshly peat-based inoculants. Treated and untreated seeds were sowed at $40 \times 20 \mathrm{~cm}$ planting distance. Observations were made at $30 \mathrm{~d}$ after planting for shoot height, shoot weight and number of nodules and at harvesting for number of pods, pod filling and seed yield.

Statistical analysis: Plant growth and yield data were analyzed independently by Analysis Of Variance (ANOVA) and treatment means were separated by the Duncan Multiple Range Test (DMRT) using the SAS systems for Windows v6.12.

\section{RESULTS AND DISCUSSION}

Characteristics and viability peat-based Inoculant: Enrichment of peat material with calcium carbonate $\left(\mathrm{CaCO}_{3}\right)$ increased $\mathrm{pH}$ value (from 6.0-7.1) and micro nutrient contents (data not shown). Besides increasing $\mathrm{pH}$ materials, calcium carbonate made the materials stickier; as such it increased the binding ability of the inoculant to seed surface as described by Somasegaran and Hoben (1994).

Water content of the inoculants decreased from $40 \%$ (value at the time of peat inoculation) to about $34.1-36.6 \%$ after 12 weeks of storage periods. Similar to water content, cell viability in the carrier also decreased across inculant formulas and storage periods (Fig. 1). Higher decrease was exhibited by inoculants Crb17, Crb46, Crb47 and Crb56. The decrease of inoculants Crb17 and Crb56 have been started since the first week of storage periods. The results suggest that higher cell density at the time of peat inoculation is required to anticipate cell viability reduction; otherwise they cannot be stored for a long time period. The results also confirm that viable cell density of freshly peat- based inoculants, used to treat the soybean seeds is above $10^{7}$ cell $\mathrm{g}^{-1}$.

Soybean Response to Inoculation: Response of soybean seeds treated with Pseudomonas inoculants varied across treatments and parameters measured (Table 2). At vegetative stage (30 day after sowing), shoot height of treated plants was not significantly different from uninoculated control. The significant effects were exhibited by the number of nodules of plants treated with inoculants Crb5, Crb46, Crb47 and Crb49. Interestingly, plants treated with Crb12, Crb17, Crb24, Crb47 and Crb56 showed significant lower shoot dry weight than that of untreated control. These results were consistent with data at harvesting that showed lower number of pods and yields of plants treated by these isolates which indicate that these five inoculants have injurious effects on soybean growth. On the other hand, plants treated with Crb5, Crb46 and Crb49 significantly increased yields suggesting that these three isolates are truly plant growth promoting bacteria. In short, the overall results showed that interactions between soybean and ACC deaminaseproducing Pseudomonas in this study felled into two categories, i.e., beneficial and deleterious depending on the isolates.

As previously described, the beneficial effects of Pseudomonas Crb5, Crb46 and Crb49 could be due to the action of their ACC deaminase activities in reducing ethylene synthesis and ameliorating growth inhibition. This result is consistent with previous experiments under growth chamber conditions, which showed growth enhancement of plants treated with these isolates (Husen et al., 2009). On the other hand, the injurious effects of those five isolates (Crb12, Crb17, Crb24, Crb47 and Crb56) as exhibited by growth inhibition and yield reduction of soybean upon inoculation are beyond the expectation of the study. Whether the result is the coincidence or an accidental circumstance, the evidence that a bacterium producing ACC deaminase shows both growth-promoting as well as deleterious properties is possible as reported by Belimov et al. (2007). Further investigation on environmental factors that influence the beneficial effects of bacterial ACC deaminase activity on plant growth is required. 


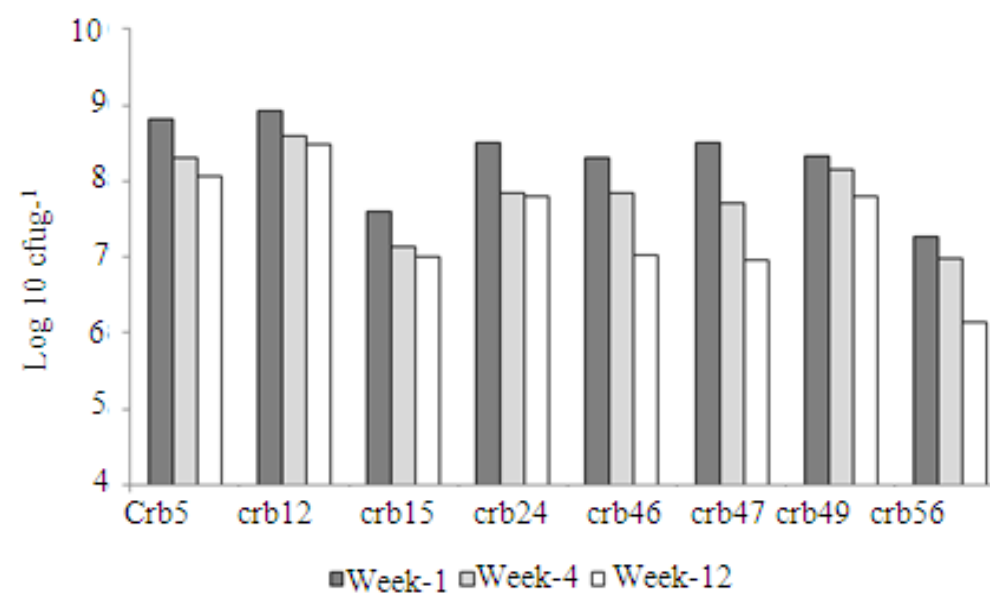

Fig.1: Cell viability in peat-based inoculants of Pseudomonas producing ACC deaminase (isolates Crb5 to Crb56) at three periods of storage

Table 2: $\quad$ Soybean response to ACC deaminase-producing Pseudomonas under field soil conditions

\begin{tabular}{|c|c|c|c|c|c|c|}
\hline Isolates & $\begin{array}{l}\text { Shoot height } \\
(\mathrm{cm})\end{array}$ & $\begin{array}{l}\text { Shoot dry } \\
\text { weight (g) }\end{array}$ & No. of nodules & No. of pods & $\begin{array}{l}\text { No. of } \\
\text { Pod filling }\end{array}$ & $\begin{array}{l}\text { Seed dry } \\
\text { weight }(\mathrm{g})\end{array}$ \\
\hline Crb5 & $16.8 \mathrm{ab}$ & $15.0 \mathrm{a}$ & $21.2 \mathrm{~b}$ & $44.2 \mathrm{a}$ & $19.7 \mathrm{a}$ & $3.29 \mathrm{a}$ \\
\hline Crb12 & $14.5 \mathrm{ab}$ & $12.3 \mathrm{~d}$ & $15.0 \mathrm{~d}$ & $33.4 \mathrm{c}$ & $11.9 \mathrm{e}$ & $1.84 \mathrm{fg}$ \\
\hline Crb17 & $17.2 \mathrm{a}$ & $13.8 b$ & $20.4 b c$ & $43.2 \mathrm{a}$ & $15.8 \mathrm{c}$ & $2.57 \mathrm{~d}$ \\
\hline $\mathrm{Crb} 24$ & $14.8 \mathrm{ab}$ & $12.5 \mathrm{~d}$ & $16.6 \mathrm{~d}$ & $33.5 c$ & $12.0 \mathrm{e}$ & $2.03 \mathrm{fg}$ \\
\hline Crb46 & $16.1 \mathrm{ab}$ & $14.9 \mathrm{ab}$ & $21.4 \mathrm{~b}$ & $36.6 b c$ & $17.8 \mathrm{~b}$ & $3.04 \mathrm{~b}$ \\
\hline Crb47 & $14.4 \mathrm{~b}$ & $13.7 \mathrm{bc}$ & $25.8 \mathrm{a}$ & $38.5 b$ & $13.5 \mathrm{~d}$ & $2.28 \mathrm{e}$ \\
\hline Crb49 & $14.7 \mathrm{ab}$ & $14.5 \mathrm{ab}$ & $21.4 \mathrm{~b}$ & $39.5 b$ & 19.1a & $3.41 \mathrm{a}$ \\
\hline Crb56 & $15.1 \mathrm{ab}$ & $12.6 \mathrm{~cd}$ & $16.8 \mathrm{~d}$ & $33.9 \mathrm{c}$ & $12.8 \mathrm{de}$ & $2.07 \mathrm{f}$ \\
\hline Untreated & $15.0 \mathrm{ab}$ & $15.6 \mathrm{a}$ & $17.8 \mathrm{~cd}$ & $43.0 \mathrm{a}$ & $15.8 \mathrm{c}$ & $2.77 \mathrm{c}$ \\
\hline
\end{tabular}

Means in a column followed by the same letter are not significantly different at $5 \%$ level by DMRT

\section{CONCLUSION}

Bacteria having ACC deaminase activities could be truly plant growth promoting bacteria providing that their beneficial effects on plant growth are consistent at a wide range of the environmental conditions. Three out of eight ACC deaminase-producing Pseudomonas used in the study increased soybean growth and yield under field soil conditions, whereas those five remaining bacteria showed deleterious effects. The possibility that some environmental factors influence or cover the beneficial effects of bacterial ACC deaminase activity cannot be excluded from consideration.

\section{ACKNOWLEDGMENT}

This study was supported by a grant from the Collaborative Research Project of KKP3T between the Agency for Agricultural Research and Development (AARD), Indonesian Ministry of Agriculture and Bogor Agricultural University (IPB) awarded to ATW.

\section{REFERENCES}

Abeles, F.B., P.W. Morgan and M.E. Saltveit, 1992. Ethylene in Plant Biology. 2nd Edn., Academic Press, San Diego, ISBN: 0120414511, pp: 414.

Belimov, A.A., F.I. Safranova, T.A. Sergeyeva, T.N. Egorova and V.A. Matveyeva, et al., 2001. Characterization of plant growth promoting rhizobacteria isolated from polluted soils and containing 1-aminocyclopropane-1-carboxylate deaminase. Can J. Microbiol., 47: 642-652. DOI: 10.1139/w01-062

Belimov A.A., V.I. Safronova and T. Mimura, 2002. Response of spring rape (Brassica napus var. oleifera L.) to inoculation with plant growth promoting rhizobacteria containing 1aminocyclopropane-1-carboxylate deaminase depends on nutrient status of the plant. Can J. Microbiol., 48: 189-199. DOI: 10.1139/w02-007

Belimov, A.A., I.C. Dodd, V. I. Safronova, N. Hontzeas and W. J. Davies. et al., 2007. Pseudomonas brassicacearum strain Am3 containing 1aminocyclopropane-1-carboxylate deaminase can 
show both pathogenic and growth-promoting properties in its interaction with tomato. J. Exper. Bot., 58: 1485-1495. DOI: 10.1093/jxb/erm010

Cattelan, A.J., P.G. Hartel and J.J Fuhrmann, 1999. Screening for plant growth-promoting rhizobacteria to promote early soybean growth. Soil Sci. Soc. Am. J. 63: 1670-1680. DOI: 10.2136/sssaj1999.6361670x

Dey, R., K.K. Pal, D.M. Bhatt and S.M. Chauhan, 2004. Growth promotion and yield enhancement of peanut (Arachis hypogaea L.) by application of plant growth-promoting rhizobacteria. Microbiol. Res., 159: 371-394. DOI: 10.1016/j.micres.2004.08.004

Dworkin, M. and J. Foster, 1958. Experiments with some microorganisms which utilize ethane and hydrogen. J. Bacteriol., 75: 592-601. PMID: 13538930

Glick, B.R., D.M. Karaturovic and P.C. Newell, 1995. A novel procedure for rapid isolation of plant growth promoting pseudomonads. Can. J. Microbiol., 41: 533-536. DOI: 10.1139/m95-070

Glick, B.R., D.M. Penrose and J. Li, 1998. A model for the lowering of plant ethylene concentrations by plant growth promoting bacteria. J. Theory Biol., 190: 63-68. DOI: 10.1006/jtbi.1997.0532

Glick, B.R., B. Todorovic, J. Czarny, Z. Cheng and J. Duan, et al., 2007. Promotion of plant growth by bacterial ACC deaminase. Crit. Rev. Plant Sci., 26: 227-242. DOI: 10.1080/07352680701572966

Grichko, V.P. and B.R. Glick, 2001. Amelioration of flooding stress by ACC deaminase-containing plant growth promoting bacteria. Plant Physiol. Biochem., 39: 11-17. DOI: 10.1016/S09819428(00)01212-2

Honma, M. and T. Shimomura, 1978. Metabolism of 1aminocyclopropane-1-carboxylic acid. Agric. Biol. Chem., 42: 1825-1831. DOI: JST.Journalarchive/bbb1961/42.1825

Husen, E., A.T. Wahyudi, A. Suwanto and R. Saraswati, 2009. Soybean seedling root growth promotion by 1-aminocyclopropane-1-carboxylate deaminase-producing pseudomonads. Indonesian J. Agric. $\quad$ Sci., $\quad 10$ : 19-25. http://pustaka.litbang.deptan.go.id/publikasi/as101 093.pdf

Jacobson, C.B., J.J. Pasternak and B.R. Glick, 1994. Partial purification and characterization of ACC deaminase from the plant growth promoting rhizobacterium. Pseudomonas putida GR12-2. Can. J. Microbiol., 40: 1019-1022. DOI: 10.1139/m94-162
Ma, W., F.C. Guinel and B.R. Glick, 2003. Rhizobium leguminosarum Biovar viciae 1aminocyclopropane-1-carboxylate deaminase promotes nodulation of pea plants. Appl. Environ. Microbiol., 69: 4396-4402. DOI: 10.1128/AEM.69.8.4396-4402.2003

Mayak, S., T. Tirosh and B.R. Glick, 1997. The Influence of Plant Growth Promoting rhizoba Cterium Pseudomonas Putida GR12-2 In: Plant Growth-Promoting Rhizobacteria, Present status and Future Prospects. Ogoshi, A., (Ed.). JapanOECD Joint Workshop, Sapporo, Japan, pp: 313315. ISBN: 4-9900627-0-1

Mayak, S., T. Tirosh and B.R. Glick, 2004. Plant growth-promoting bacteria that confer resistance to water stress in tomato and pepper. Plant Sci., 166: 525-530. DOI: 10.1016/j.plantsci.2003.10.025

Penrose, D.M., B.A. Moffatt and B.R. Glick, 2001. Determination of 1-Aminocyclopropane-1Carboxylic Acid (ACC) to assess the effects of ACC deaminase-containing bacteria on roots of canola seedlings. Can. J. Microbiol., 47: 77-80. DOI: 10.1139/w00-128

Reed, M.I.E. and B.R. Glick, 2005. Growth of canola (Brassica napus) in the presence of plant growthpromoting rhizobacteria and either copper or polycyclic aromatic hydrocarbons. Can. J. Microbiol., 51: 1061-1069. DOI: 10.1139/w05-094

Saravanakumar, D. and R. Samiyappan, 2007. ACC deaminase from Pseudomonas fluorescens mediated saline resistance in groundnut (Arachis hypogea) plants. J. Applied Microbiol., 102: 12831292. DOI: 10.1111/j.1365-2672.2006.03179.x

Shaharoona, B., M. Arshad, Z.A. Zahir and A. Khalid, 2006. Performance of Pseudomonas spp. containing ACC-deaminase for improving growth and yield of maize (Zea mays L.) in the presence of nitrogenous fertilizer. Soil Biol. Biochem., 38: 2971-2975. DOI: 10.1016/j.soilbio.2006.03.024

Shaharoona, B., G.M. Jamro, Z.A. Zahir, M. Arshad and K.S. Memon, et al., 2007. Effectiveness of various Pseudomonas spp. and Burkholderia caryophylli containing ACC deaminase for improving growth and yield of wheat (Triticum aestivum L.). J. Microbiol. Biotechnol., 17: 1300-307. http://cat.inist.fr/?aModele $=$ afficheN\&cpsidt $=1903$ 3686

Somasegaran, P. and H.J. Hoben, 1994. Handbook for Rhizobia, Methods in Legum-Rhizobium Technology. Springer-Verlag, New York, ISBN: 3540-94134-7, pp: 450. 
Wang, C., E. Knill, B.R. Glick and G. Defago, 2000. Effect of transferring 1-aminocyclopropane-1carboxylic acid (ACC) deaminase gene into Pseudomonas fluorescens Strain CHA0 and its gacA derivative CHA96 on their growth-promoting and disease-suppressive capacities. Can. J. Microbiol., 46: 898-907. DOI: 10.1139/w00-071
Zuberer, D.A., 1994. Recovery and Enumeration of Viable Bacteria. In: Methods of Soil Analysis, Part 2 Microbiological and Biochemical Properties, Weaver, R.W., S. Angle, P. BottomLey, D. Smith and S. Tabatabai, (Eds.). SSSA, Inc., USA., pp 119-144. ISBN: 0-89118$810-\mathrm{X}$ 